\title{
PENERAPAN STANDARISASI LAPORAN KEUANGAN UMKM BAGI PENGUSAHA KECIL MENENGAH UNTUK MENINGKATKAN KINERJA USAHA
}

\author{
Surjono, Prasetio Ariwibowo, Mima Nizma. \\ Universitas Indraprasta PGRI Jakarta \\ prasetio.ariwibowo@yahoo.com
}

\begin{abstract}
Abstrak
Dalam kegiatan Pengabdian Kepada Masyarakat (ABDIMAS) ini peserta yang dilibatkan adalah semua pelaku kuliner UMKM, 3 orang perwakilan dari masing-masing RT yang telah dipilih oleh Lembaga Pengelola-Perkampungan Budaya Betawi (LP-PBB). Dari hasil survey awal, warga di lokasi Setu Babakan sangat mengharapkan pengetahuan dan keterampilan tentang mengolah usaha khususnya di bidang keuangan untuk mensejahterakan taraf hidup. Pertimbangan memilih warga sebagai peserta pelatihan abdimas ini para pengusaha kecil menengah yang bergerak di bidang usaha kuliner adalah agar hasil pelatihan segera diterapkan dan merasakan hasil pelatihan yang diberikan dengan segera. Diharapkan nantinya tingkat kesadaran dan keingintahuan yang semakin meningkat dalam tata kelola keuangan usaha dan tidak adanya rasa takut terhadap perbankan dan non perbankan yang melekat pada diri setiap pelaku usaha kuliner disekitar Setu Babakan.
\end{abstract}

Kata Kunci : Laporan Keuangan, Akuntansi, Setu Babakan, UMKM, Betawi

\begin{abstract}
In this Community Service (ABDIMAS) activity, the participants involved were all MSME culinary actors, 3 representatives from each RT who had been chosen by the Betawi Cultural Village-Management Institute (LP-PBB). From the results of the initial survey, residents in the Setu Babakan location were looking forward to the knowledge and skills of business processing, especially in the financial sector to prosper the standard of living. The consideration of choosing citizens as abdimas trainees is that small and medium entrepreneurs engaged in the culinary business are so that the results of the training are immediately implemented and feel the results of the training provided immediately. It is expected that later the level of awareness and curiosity will increase in the management of business finance and the absence of fear of banks and nonbanking that is inherent in every culinary business actor around Setu Babakan.
\end{abstract}

Keywords: Financial Report, Accounting, Setu Babakan, UMKM, Betawi

\section{PENDAHULUAN}

Usaha Kecil dan Menengah dewasa ini telah menjadi salah satu sektor penopang utama kemajuan perekonomian Indonesia dan menjadi sektor usaha yang tidak runtuh diakibatkan krisis moneter nasional yang dialami oleh Indonesia pada tahun 1997 dan tahun 2008 lalu. Definisi Usaha Mikro Kecil dan Menengah (UMKM) memiliki batasan yang bervariasi. 
Sesuai dengan Undang - undang nomor 20 tahun 2008 tentang Usaha Mikro, Kecil dan Menengah (UMKM). Usaha Mikro adalah usaha produktif milik orang perorangan dan/atau badan usaha perorangan yang memenuhi kriteria Usaha Mikro sebagaimana diatur dalam Undang-Undang ini.

Usaha Kecil adalah usaha ekonomi produktif yang berdiri sendiri, yang dilakukan oleh orang perorangan atau badan usaha yang bukan merupakan anak perusahaan atau bukan cabang perusahaan yang dimiliki, dikuasai, atau menjadi bagian baik langsung maupun tidak langsung dari usaha menengah atau usaha besar yang memenuhi kriteria Usaha Kecil sebagaimana dimaksud dalam Undang-Undang ini.

Usaha Menengah adalah usaha ekonomi produktif yang berdiri sendiri, yang dilakukan oleh orang perseorangan atau badan usaha yang bukan merupakan anak perusahaan atau cabang perusahaan yang dimiliki, dikuasai, atau menjadi bagian baik langsung maupun tidak langsung dengan Usaha Kecil atau usaha besar dengan jumlah kekayaan bersih atau hasil penjualan tahunan sebagaimana diatur dalam UndangUndang ini.

Hingga saat ini, jumlah pengusaha UMKM di Indonesia mengalami kenaikan yang sangat signifikan. Namun hal yang sangat membanggakan ini hanya dilihat dari sisi kuantitas tanpa melihat dari sisi kualitas usaha, khususnya dari aspek finansial. Hanya sedikit pengusaha UMKM yang memperhatikan aspek finansial.

Hal ini dikarenakan kurangnya sosialisasi dan ketidaksadaran para pengusaha UMKM memperhatikan pengelolaan keuangan demi kemajuan usahanya. Pengelolaan keuangan merupakan aspek utama dalam memajukan usaha. Pengelolaan keuangan dapat dilakukan dengan laporan keuangan
(Akuntansi) usaha sederhana. Akuntansi adalah metoed pencatatan secara sistematis yang menyajikan proses laju keuangan secara sistematis guna menghasilkan informasi keuangan dalam pengambilan keputusan bagi pengguna dari laporan keuangan tersebut.

Sepanjang uang digunakan oleh para pengusaha UMKM sebagai alat tukar, para pengusaha UMKM membutuhkan laporan akuntansi. Manfaat laporan akuntansi terhadap para pelaku UKM, antara lain: (1) UMKM dapat mengetahui kinerja keuangan perusahaan, (2) UMKM dapat mengetahui, memilah, dan membedakan harta perusahaan dan harta pemilik, (3) UMKM dapat mengetahui posisi dana baik sumber maupun penggunaannya, (4) UMKM dapat membuat anggaran yang tepat, (5) UMKM dapat menghitung pajak, (6) UMKM dapat mengetahui aliran uang tunai selama periode tertentu, dan (7) dapat meyakinkan pihak lembaga keuangan dalam memberikan bantuan modal usaha bagi UMKM. Pengertian Akuntansi, menurut Abubakar A \& Wibowo (2004), adalah proses identifikasi, pencatatan dan komunikasi terhadap transaksi ekonomi dari suatu entitas/perusahaan. Akuntansi merupakan kegitn proses analisis keuangan yang memiliki 3 kegiatan utama yaitu: pertama, aktivitas identifikasi merupakan kegiatan mengidentifikasikan transaksi-transaksi yang terjadi dalam perusahaan. Kedua, aktivitas pencatatan adalah aktivitas yang mencatat berbagai transaksi yang telah diidentifikasi secara kronologis dan sistematis. Aktivitas ketiga adalah komunikasi yaitu informasi akuntansi yang dikomunikasikan dalam bentuk laporan keuangan kepada pihak yang berkepentingan baik internal perusahaan maupun pihak eksternal pelaku usaha.

Akuntansi seringkali digunakan oleh perusahaan berguna untuk 
memberikan informasi yang berupa data-data keuangan perusahaan guna pengambilan keputusan perusahaan.

Dalam menjalankan aktivitas sehari-hari, diperlukan beberapa informasi khususnya di bidang keuangan, diantaranya informasi nilai perusahaan dan informasi laba/rugi perusahaan. Kedua informasi tersebut diperlukan untuk mengetahui seberapa besar perusahaan memiliki modal, perkembangan atau maju mundurnya keuangan perusahaan dapat diketahui, sebagai dasar untuk perhitungan pajak, dapat diketahui kondisi perusahaan saat dibutuhkan memerlukan loan dari bank atau pihak lain, sebagai dasar untuk menentukan kebijakan yang akan ditempuh perusahaan, Menarik minat investor saham jika perusahaan berbentuk PT (Perseroan Terbatas).

Jika Akuntansi sebagai suatu sistem, di dalam akuntansi terdapat berbagai konsep pemikiran dasar keuangan. Asumsi dasar tersebut antara lain: Business Entity, asumsi pemikiran ini beranggapan jika aktiva suatu perusahaan harus dipisahkan dari aktiva orang pribadi yang menyediakan aktiva (modal) untuk dipergunakan dalam operasional perusahaan tersebut.

Dalam ilmu akuntansi, dalam pembukuan laporan keuangan perusahaan mengeluarkan berbagai definisi dari konsep kesatuan usaha, utang dan biaya pribadi pemilik ketika pemilik usaha memiliki aktiva, utang dan pendapatan perusahaan sehingga segala utang dan biaya pribadi harus diperhitungkan terpisah dari perusahaan. Kedua asumsi Going Concern, Dalam konsep ini dalam jangka waktu tertentu perusahaan berdiri dan beroperasional contohnya perusahaan yang ingin mendirikan perusahaannya menjadi berbentuk Perseroan Terbatas di Indonesia membutuhkan waktu 75 tahun sehingga tercipta asumsi bahwa selama watu tersebut perusahaan masih tetap beroperasional dan menghasilkan keuntungan, maka perusahaan yang dimiliki dapat beroperasional secara terus menerus dalam waktu yang tidak terbatas.

Asumsi berikutnya adalah Time Periods, dalam menjalankan operasional perusahaan hendaknya mempertimbangkan berbagai hal sebagai landasan dalam pengambilan keputusan baik berdasarkan pemikiran para stakeholder maupun stockholder perusahaan yang berkepentingan selama berlangsungnya operasional perusahaan. Untuk menampung hal tersebut, perusahaan hendaknya membuat laporan keuangan perusahaan untuk jangka waktu satu tahun transaksi operasional perusahaan. Keempat yaitu Money Measurement, Semua transaksi perusahaan dicatat dan dapat diukur dengan satuan tertentu contohnya Rp., \$, Ruppee, Bath, dll.

Kelima, Harta Perolehan (Costing of Assets) adalah seluruh aktiva pada umumnya dibukukan sebesar harga perolehannya. Asumsi berikutnya adalah Dual Aspect yaitu setiap pencatatan suatu kejadian atau transaksi akan berpengaruh pada sedikitnya dua akun perkiraan dalam pembukuan. Asumsi keenam adalah Accrual Concept, Asumsi ini merupakan perhitungan laba/rugi perusahaan yang menekankan suatu kejadian pada suatu periode tertentu baik merupakan biaya maupun hasil. Jika para pengusaha UMKM memahami akan pentingnya akuntansi dalam menjalankan usahanya.

Pengusaha UMKM pasti akan selalu menjadikan pedoman dasar dalam melakukan perencanaan usaha. Karena dengan akuntansi, UMKM dapat mengetahui berbagai hal yang diperbuat ketika mengalami kerugian dan laba. Ketika laba yang diperoleh semakin meningkat dengan tata kelola keuangan yang baik, maka UMKM dapat menjadi 
solusi utama bagi pemerintah bagi berbagai permasalahan perekonomian.

Permasalahan Mitra Berdasarkan dari perihal yang peneliti paparkan sebelumnya, bahwa para pelaku UMKM di kawasan budaya betawi Setu Babakan yang berlokasi di jalan. Mochammad Kahfi II, Setu Babakan, Kel. Srengseng Sawah, Kec. Jagakarsa, Jakarta Selatan belum memiliki kesadaran para pelaku UMKM tentang tata kelola keuangan usaha kecil yang sesuai stanar akuntansi sederhana yang khususnya mengenai manajemen keuangan dan manajemen bank dan pengetahuan mengenai bank dan non lembaga keuangan.

Target Luaran Para pelaku UMKM dapat memiliki pengetahuan tentang Akuntansi UMKM yang sederhana, manajemen umum, dan bank dan lembaga keuangan. Menanamkan kesadaran para pelaku usaha kecil menengah tentang arti pentingnya Akuntansi UMKM yang sederhana dan manajemen umum, dan bank dan lembaga keuangan. Terciptanya buku pedoman dan standarisasi tata kelola keuangan usaha bagi para pelaku UMKM Sebagai langkah awal dalam rangka melaksanakan penelitian lanjutan dan program pengabdian masyarakat selanjutnya.

\section{METODE PELAKSANAAN}

Sasaran Kegiatan Sasaran kegiatan pengabdian ini adalah para pelaku UMKM di sekitar kawasan perkampungan budaya betawi Setu Babakan.

Dalam kegiatan ini peserta yang dilibatkan adalah semua pelaku kuliner UMKM, 3 orang perwakilan dari masing-masing RT yang telah dipilih oleh Lembaga Pengelola-Perkampungan Budaya Betawi (LP-PBB). Dari hasil survey awal, warga di lokasi Setu Babakan sangat mengharapkan pengetahuan dan keterampilan tentang mengolah usaha khususnya di bidang keuangan untuk mensejahterakan taraf hidup.

Pertimbangan memilih warga yang telah dan akan menjalankan usaha kuliner sebagai kategori peserta pelatihan ini adalah agar hasil pelatihan segera diterapkan dan merasakan hasil pelatihan yang diberikan dengan segera. Diharapkan nantinya tingkat kesadaran dan keingintahuan yang semakin meningkat dalam tata kelola keuangan usaha dan tidak adanya rasa takut terhadap parbankan dan lembaga non perbankan yang melekat pada diri setiap pelaku usaha kuliner disekitar Setu Babakan.

Berdasarkan potensi yang dimiliki oleh Setu Babakan, para pelaku UMKM disekitar danau sangat bervariasi, baik dari skala bisnis, jenis kuliner dan fasilitas yang digunakan. Perlu adanya motivasi baik dalam bentuk penyuluhan, pelatihan sampai pengawasan yang berkelanjutan. Berdasarkan hasil survai yang telah dilakukan Tim, pelaku usaha pada skala UMKM belum memperhatikan manajemen keuangan yang baik dan benar dan masih memiliki rasa takut yang tinggi terhadap bank dan lembaga keuangan yang tinggi dalam menjalankan dan memulai usaha kuliner.

Metode Kegiatan abdimas ini dilakukan dengan tim abdimas unindra mendatangi aula pertemuan kantor pengelola Setu Babakan. Para pelaku UMKM berkumpul di aula kantor Lembaga Pengelola Perkampungan Budaya Betawi Setu Babakan, Jakarta Selatan, kemudian diberikan materi tentang tata kelola keuangan sederhana dan perbankan yang memperhatikan cara menjurnal dan memindahbukukan, menyusun daftar saldo dan mencatat penyesuaian, menyusun daftar saldo setelah penyesuaian, dan menyusun laporan keuangan.

Selanjutnya, diberikan uraian tentang hasil yang akan diperoleh akan 
untung dan ruginya dalam mengajukan pinjaman modal usaha lewat perbankan dan rentenir. Dengan demikian hasil penjualan meningkat, kesejahteraan semakin membaik, serta menghilangkan rasa takut terhadap lembaga keuangan plat merah maupun bukan plat merah dan ketergantungan terhadap rentenir.

Untuk menambah keyakinan warga, dalam menambah income keluarga dari pengelolaan kuliner yang berhasil, akan didatangkan nara sumber yang telah sukses menjalankan program tersebut. Satu bulan kemudian diadakan evaluasi keberhasilan kegiatan. Kegiatan ini menggunakan konsep penyuluhan, dimana peserta diberi pembekalan. Dari pembekalan tersebut diharapkan menghasilkan sebuah mindset, sehingga nantinya peserta tidak pasif tapi terjadi dialog interaktif yang pada akhirnya mampu mengaplikasikan apa yang diperoleh dari penyuluhan tersebut berupa sesuatu yang berharga dan bernilai ekonomis yaitu pengelolaan usaha terpadu dan standarisasi akuntansi usaha yang sederhana.

Tabel 1. Daftar Narasumber Abdimas di Setu Babakan

\begin{tabular}{|c|c|c|}
\hline No. & Jenis Uraian & Narasumber \\
\hline 1 & $\begin{array}{c}\text { Konsep Pengabdian Kepada } \\
\text { Masyarakat }\end{array}$ & Seluruh Anggota Tim Abdimas Unindra \\
\hline 2 & Konsep Manajemen Terpadu & $\begin{array}{l}\text { Drs. H. Surjono MM.; Chandra Mai, M.BA. } \\
\text { dan Prasetio Ariwibowo, S.MB. MM }\end{array}$ \\
\hline 3 & $\begin{array}{c}\text { Konsep Akuntansi UMKM } \\
\text { Sederhana }\end{array}$ & $\begin{array}{l}\text { Drs. H. Surjono MM., Ai Annisa Utami, } \\
\text { M.Ak. dan Mima Nizma, SE. MM. }\end{array}$ \\
\hline 4 & $\begin{array}{l}\text { Konsep UMKM \& Bank dan } \\
\text { Non Lembaga Keuangan }\end{array}$ & $\begin{array}{c}\text { Rudi Susanto, SE. MM. dan Prasetio } \\
\text { Ariwibowo, S.MB. MM. }\end{array}$ \\
\hline 5 & $\begin{array}{l}\text { Evaluasi Laporan Pelatihan } \\
\text { Manajemen Terpadu }\end{array}$ & Seluruh Anggota Tim Abdimas Unindra \\
\hline 6 & Pendampingan & $\begin{array}{c}\text { Seluruh Anggota Tim Abdimas UNindra } \\
\text { dan Puskanomi Unindra Jakarta }\end{array}$ \\
\hline
\end{tabular}

Sumber : Data Sekunder Penulis (2015)

Selama proses kegiatan berlangsung, peserta diberikan kesempatan untuk berkomunikasi langsung dengan Tim Pengabdian Masyarakat, baik dalam bentuk telepon, email, peserta berinterkasi langsung dengan pendamping yang selalu berada ditengah-tengah mereka.

Langkah-langkah Kegiatan Abdi Masyarakat Langkah-langkah yang dilakukan dalam pengabdian kepada masyarakat ini adalah Mengadakan penyuluhan untuk memberikan pengetahuan tentang manajemen terpadu, Akuntansi usaha sederhana, UMKM, Perbankan dan Non Lembaga Keuangan di Setu Babakan. Setiap menjelang akhir pertemuan di tiap harinya, tim memberikan pelatihan (praktik) manajemen terpadu, Akuntansi usaha sederhana, UMKM, Bank dan Lembaga Keuangan non Bank sebagai bahan evaluasi dan monitoring terhadap kegiatan pelatihan (Abdimas) di hari tersebut Pendampingan dimulai sejak penyuluhan, persiapan pelatihan, pelatihan, sampai pada saat monitoring dan evaluasi yang dibantu oleh seluruh tim Abdimas yang merupakan dosen Unindra yang terdiri dari Chandra Mai, M.BA. Rudy Susanto, SE. MM. dan Ai Annisa Utami, M.Ak. Kedua tim yang dibentuk dalam Pengabdian Masyarakat ini memiliki kepakaran yang cukup untuk melaksanakan kegiatan ini. 
Jadwal Kegiatan Kegiatan ini dilaksanakan selama 4 bulan yaitu Januari - April 2015. Adapun rencana kegiatan secara keseluruhan adalah sebagai berikut :

Tabel. 2. Jadwal Kegiatan

\begin{tabular}{ccc}
\hline NO & JENIS KEGIATAN & BULAN KE - \\
\hline 1 & Survey dan Perijinan & 1 \\
Lokasi & Penyusunan Proposal dan \\
Persiapan Pelatihan & Abdimas & 2 \\
3 & Pelaksanaan dan Evaluasi & 3 \\
4 & Abdimas & 4 \\
& Penyusunan Laporan \\
& Abdimas & 4
\end{tabular}

Sumber : Data Sekunder Penulis (2015)

Secara khusus tahapan acara pada pertemuan dalam kegiatan Abdimas adalah sebagai berikut:

Hari Pertama

Tabel. 3 Susunan Acara Pengabdian Masyarakat

\begin{tabular}{|c|c|c|c|c|}
\hline $\mathrm{NO}$ & WAKTU & ACARA & PENANGGUNG JAW & \\
\hline \multirow[t]{2}{*}{1} & $08.00-08.30$ & Registrasi Tim Peserta & $\begin{array}{ll}\text { Seluruh } & \text { Anggota } \\
\text { Abdimas } & \text { Unindra }\end{array}$ & $\begin{array}{l}\text { Tim } \\
\text { dan }\end{array}$ \\
\hline & & & Pengelola Setu Babakan & \\
\hline \multirow[t]{15}{*}{2} & $08.30-09.30$ & 1. Sambutan dari Ketua & Seluruh Anggota & Tim \\
\hline & & Lembaga Pengelola & Abdimas & dan \\
\hline & & Perkampungan Budaya & Pengelola Setu Babakan & \\
\hline & & Betawi (LP-PBB) Setu & & \\
\hline & & Babakan & & \\
\hline & & 2. Sambutan & & \\
\hline & & Universitas Indraprasta & & \\
\hline & & PGRI (Unindra) & & \\
\hline & & 3. Sambutan Kepala Unit & & \\
\hline & & Pengelola Kawasan & & \\
\hline & & Perkampungan Budaya & & \\
\hline & & Betawi_dr. H. Abdul & & \\
\hline & & Syukur, SKM. Dr. H. & & \\
\hline & & Achmad Sjamsuri, SE. & & \\
\hline & & MM. H.E. Supli Ali & & \\
\hline \multirow[t]{3}{*}{3} & $09.30-11.00$ & Konsep UMKM dan & Alm. Drs. H. Surjono & \\
\hline & & Bank \& Non Lembaga & MM., Rudy Susanto, SE. & \\
\hline & & Keuangan & $\begin{array}{l}\text { MM. dan Prasetio } \\
\text { Ariwibowo S.MB. MM. }\end{array}$ & \\
\hline
\end{tabular}




$\begin{array}{llll}4 & 11.00-11.30 & \text { Tanya Jawab } & \begin{array}{l}\text { Seluruh Anggota } \\ \text { Abdimas Unindra }\end{array}\end{array}$

Sumber : Data Primer Penulis (2015)

Hari Kedua

Tabel. 4 Susunan Acara Pengabdian Masyarakat

\begin{tabular}{|c|c|c|c|}
\hline NO & WAKTU & ACARA & PENANGGUNG JAWAB \\
\hline & $08.00-08.30$ & Registrasi Tim & Seluruh Anggota \\
\hline 1 & & Peserta Pelatihan & $\begin{array}{c}\text { Tim Abdimas } \\
\text { Unindra }\end{array}$ \\
\hline 2 & $08.30-10.30$ & $\begin{array}{c}\text { Konsep } \\
\text { Manajemen } \\
\text { Umum Terpadu }\end{array}$ & $\begin{array}{l}\text { Prasetio Ariwibowo, } \\
\text { S.MB. MM. }\end{array}$ \\
\hline 3 & $10.30-11.00$ & $\begin{array}{c}\text { Konsep } \\
\text { Akuntansi } \\
\text { Sederhana } \\
\text { UMKM }\end{array}$ & $\begin{array}{c}\text { Mima Nizma, SE. } \\
\text { MM. }\end{array}$ \\
\hline 4 & $11.00-11.30$ & Tanya Jawab & $\begin{array}{l}\text { Seluruh Anggota } \\
\text { Tim Abdimas } \\
\text { Unindra }\end{array}$ \\
\hline
\end{tabular}

Sumber : Data Primer Penulis (2015)

Hari Ketiga

Tabel. 5 Susunan Acara Pengabdian Masyarakat

\begin{tabular}{cccc}
\hline NO & WAKTU & ACARA & PENANGGUNG JAWAB \\
\hline \multirow{2}{*}{1} & $08.00-$ & Registrasi Tim & Seluruh Anggota \\
& 08.30 & Peserta Pelatihan & Tim Abdimas \\
& & Unindra \\
2 & $08.30-$ & Akuntansi & Ai Annisa Utami, \\
& 11.00 & Sederhana & M.Ak. dan Mima \\
& $11.00-$ & UMKM & Nizma SE. MM. \\
& 12.00 & Tanya Jawab dan & Tim Abdimas \\
& & Ramah Tamah & Unindra dan \\
3 & & (Penutupan) & Pengelola \\
& & & Perkampungan \\
& & & Budaya Betawi (LP- \\
& & & PBB) Setu Babakan \\
\end{tabular}

Sumber : Data Primer Penulis (2015)

\section{HASIL DAN PEMBAHASAN}

Ketika kegiatan pengabdian kepada masyarakat ini dilaksanakan, para peserta pelatihan ini merasakan benefit yang sangat besar. Hal ini dikarenakan para peserta memperoleh banyak pengetahuan dan praktik mengenai penyusunan laporan keuangan sederhana bagi pengusaha kecil dan menengah.

Koordinasi dan kerjasama yang dilakukan antara Unindra dalam hal ini pelaksana kegiatan pengabdian masyarakat di Setu Babakan, sudah sangat baik. Pihak Pengelola Setu Babakan sangat menyambut dengan baik 
kegiatan yang dapat meningkatkan kemampuan para anggotanya (pengusaha UMKM khas Betawi) melalui kerja sama dengan pihak Unindra, terutama yang berkaitan dengan pendidikan dan pelatihan.

Namun diperoleh berbagai masukan bagi pelaksana kegiatan ini, yaitu jumlah peserta yang diundang kurang dapat memenuhi harapan dari Unindra dan Pihak LP-PBB, mereka mengharapkan kegiatan seperti ini hendaknya dapat dilakukan dengan peserta yang lebih banyak dari saat ini, karena kegiatan ini sangat penting untuk meningkatkan profesionalisme bagi mereka selaku pemilik usaha UMKM Kuliner (makanan dan minuman), Batik, Handycraft khas Betawi.

Jika dilihat dari total kehadiran dari sejumlah undangan yang disebarkan, sesungguhnya jumlah jumlah kehadiran peserta pelatihan saat pelatihan cukup baik, yaitu telah mencapai $90 \%$, hal ini menunjukkan bahwa sasaran kegiatan ini sangat antusias mengikuti pelaksanaan kegiatan yang dilakukan ini dan disertai dengan adanya doorprize yang disediakan oleh pemateri. Banyak pertanyaan dan diskusi yang dilakukan tidak dapat dibahas secara mendalam karena keterbatasan waktu pelaksanaan kegiatan mengenai tata cara kelola usaha (manajemen usaha), pengetahuan mengenai lembaga keuangan (Perbankan dan Non Perbankan plat merah maupun non plat merah) terutama mengenai tata cara atau peraturan terbaru mengenai pengajuan modal usaha dengan baik dan benar. Selain itu, pembuatan laporan keuangan sesuai standar Akuntansi Sederhana untuk masing-masing usaha yang mempunyai karakteristik yang berbeda, belum dapat didiskusikan secara maksimal. Saat mengadakan kegiatan serupa berikutnya, diperlukan kegiatan pendampingan pembuatan laporan keuangan Akuntansi sederhana bagi UMKM yang masih kesulitan membuat laporan keuangan usaha tersebut.

\section{SIMPULAN}

Berdasarkan kegiatan pengabdian kepada masyarakat yang telah diuraikan, disimpulkan bahwa pemahaman peserta tentang pembuatan laporan keuangan sederhana UMKM semakin baik setelah mengikuti penyuluhan konsep manajemen usaha terpadu, bank dan non lembaga keuangan dan pelatihan penyusunan laporan keuangan, terutama bagi para pengusaha UMKM khas Betawi yang menjadi anggota LP-PB Betawi Setu Babakan, Kemampuan peserta pelatihan membuat laporan keuangan sederhana UMKM pada simulasi dengan bahan yang disiapkan panitia dan pemateri telah cukup baik.

Berdasarkan uraian sebelumnya, pada kesempatan ini dapat kami sarankan beberapa hal, yaitu Pelatihan tentang bidang ilmu akuntansi terutama proses dan pemahaman tentang pembuatan laporan keuangan sangat diperlukan oleh para pengusaha UMKM, sehingga diharapkan kegiatan seperti ini dapat berlanjut di kegiatan pengabdian kepada masyarakat serupa di masa yang akan datang. Bagi para pengusaha UMKM khas Betawi perlu melihat atau memperbaharui pengetahuan yang dimiliki, sesuai dengan perkembangan atau perubahan yang terjadi.

\section{DAFTAR PUSTAKA}

\section{(2013). Pengertian,} Kriteria, dan Klasifikasi UMKM. Cipatat.

http://peuyeumcipatat.blogspot.co $\underline{\mathrm{m} / 2013 / 05 / \text { pengertiankriteria-dan- }}$ klasifikasi-umkm.html. 
Abubakar, Arif \& Wibowo. (2004). Akuntansi untuk Bisnis Usaha Kecil dan Menengah. Jakarta: Penerbit PT Grasindo.

Lestari, N.P.N.E. (2014). Strategi Pemberdayaan Indutri Kecil Kerajinan Ukiran Kayu di Kabupaten Gianyar Provinsi Bali. Bali : Universitas Udayana Press : https://www.scribd.com/doc/2957 74782/Unud-79-1104976961Disertasi-Ni-Putu-Nina-Eka$\underline{\text { Lestari-1090671010 }}$

Lukman, A. (2006). Penyusunan Sistem Rekruitmen, Pembinaan Karir, Pendidikan dan Latihan, Pengawasan Serta Organisasi Tata Kerja Kejaksaan Sebagai Bagian Dari program pembaruan KeJaksaan Republik Indonesia Bidang Pembangunan Sumber Daya Manusia dan Penguatan Institusi. Jakarta. Fakultas Hukum Universitas Indonesia (MaPPIFHUI).

https://www.slideshare.net/mappif h/laporan-akhir-pelaksanaanproject-development-of-theattorney-generals-officeinstitutional-framework-for$\underline{\text { reform }}$

Mardikaningrum, P.A.R. (2010). Analisis Strategi Pemasaran Usaha Jasa Pembuatan Dan Perbaikan Furniture UD. Surya Furniture, Bogor, Jawa Barat. Bogor : IPB Press. DOI : https://www.scribd.com/document /170307349/Analisis-Strategi-

Pemasaran-Usaha-JasaPembuatan-Dan-PerbaikanFurniture-UD-Suryani-FurnitureBogor-Jawa-Barat.

Pemerintah Provinsi DKI Jakarta. (2012). Laporan Penyelenggaraan Pemerintahan Daerah Akhir Masa
Jabatan Tahun 2007 - 2012. Jakarta.

http://docplayer.info/29596462-

Laporan-penyelenggaraanpemerintahan-daerah-akhir-masajabatan-tahun.html.

Pratiko, B. (2013). Manajemen Keuangan Perusahaan. Jakarta : Gunadharma Press. http://budipratiko9.blogspot.com/ 2013/11/manajemen-keuanganperusahaan.html.

Risaldi, A. (2013). Perbenihan Ikan Nila (Oreocromis Niloticus) Di Balai Benih Ikan (BBI) Air Tawar Ompo Kabupaten Soppeng. Bone. http://infoichal28.blogspot.com/2 013/11/laporan-perbenihan-ikannila-di-balai.html

Safiq, Muhammad, Rudi Syaefudin, Satriyo Budi P., Wahyu Pribadi, Anton Harto K. (2014). Konversi PSAK ke IFRS. Jakarta : Gunadharma Press. https://antonhartokencono.wordpr ess.com/2014/06/30/konvergensipsak-ke-ifrs/

Setyorini, D., Sagoro, Endra Mukti, Nugroho, Mahendra Adhi, dan Istiningrum, Andian Ari. (2012). Pelatihan Akuntansi Usaha Mikro Kecil Menengah (UMKM) Untuk Meningkatkan Kinerja Keuangan Perusahaan. Yogyakarta : UNY Press.

http://docplayer.info/37040373-

Laporan-kegiatan-programpengabdian-pada-masyarakat.html

Simatupang, J. (2009). Membangun Kompetensi Mewujudkan Strategi. https://johannessimatupang.wordp ress.com/2009/06/01/membangun -kompetensi-mewujudkanstrategi/ 